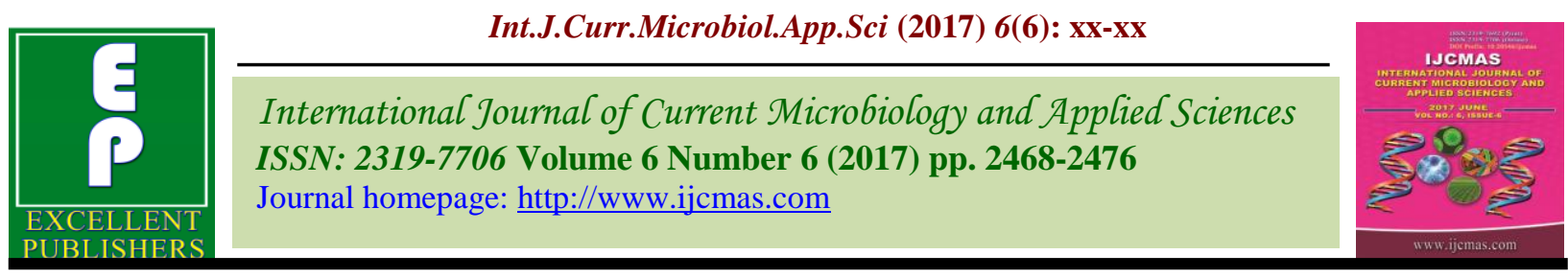

Review Article

https://doi.org/10.20546/ijcmas.2017.606.293

\title{
Use of Acoustics as Non-Destructive Techniques: A Review
}

\author{
Shrikrishna Nishani ${ }^{1}$, Shrinivas Deshpande ${ }^{2}$ and Gajanan Gundewadi ${ }^{1}$ \\ ${ }^{1}$ Indian Agricultural Research Institute, New Delhi, India \\ ${ }^{2}$ University of Agricultural Sciences, Raichur, Karnataka, India \\ *Corresponding author
}

\begin{tabular}{|c|c|}
\hline & A B S T R A C T \\
\hline $\begin{array}{l}\text { Acoustic vibration, } \\
\text { Quality, Texture, } \\
\text { Perishables and } \\
\text { Non-destructive } \\
\text { technique }\end{array}$ & \multirow{3}{*}{$\begin{array}{l}\text { The perishable commodities after maturity they undergo the stage of ripening and tissue } \\
\text { softening. The change in texture of fruits and vegetables occurs due to the breakdown of } \\
\text { pectin substance in the middle lamella and the measurement of tissue softening is an } \\
\text { important parameter to determine the shelf life of that commodity. Measurements of } \\
\text { quality parameters have traditionally been carried out using a texture analyzer or } \\
\text { penetrometer in reference texture tests. These traditional techniques are destructives means } \\
\text { of analysis. In this review we reported about the Acoustic Vibration Technology (AVT), a } \\
\text { non-destructive method of estimating the quality parameters of the food products. This } \\
\text { technique was employed to detect responses to imposed vibration of intact food material } \\
\text { using a shaker. A fast Fourier transform algorithm was used to process response signals } \\
\text { and the desired results were extracted. This review explains the capability of the AVT and } \\
\text { the vibration response data for predicting quality and the significant advantage for } \\
\text { commercial scale equipment's. }\end{array}$} \\
\hline Article Info & \\
\hline $\begin{array}{l}\text { Accepted: } \\
\text { 29 May } 2017 \\
\text { Available Online: } \\
10 \text { June } 2017\end{array}$ & \\
\hline
\end{tabular}

\section{Introduction}

The quality is comparative degree of excellence of a particular product. Quality is the combination both internal variables (firmness, sugar content, acid content and internal defects) and external variables (shape, size, external defects and damage) of the product. Increasing consumer demand for high-quality product has led to the development of novel technologies for quality assessment like optical, acoustic and mechanical sensors. Presently these quality variables are assessed by destructive method in which the entire product sample is disturbed. Due adoption of destructive method of quality assessment, the loss of product quantity may takes happen. These traditional processes involve lot of chemical analysis, calculations and mainly time consuming. But processors are needed to measure these quality variables in a nondestructive manner to retain its inherent characteristics. This problem initiates the researchers and manufacturers to develop non-destructive techniques. In this modern life style the consumers are focusing on the quality of the products while purchasing; therefore, evaluation of the quality of the products is important not only to farmers but to food processors and distributors also. There are various factors in quality evaluation, such as appearance, taste, and fragrance, among which, texture is an important attribute. Desired textures include hardness, crispness, juiciness, and mealiness (Mitsuru and Naoki, 
2010). According to British Standards Institution, the texture of an edible material is defined as the attribute of a substance resulting from a combination of physical properties perceived by the senses of touch, sight and hearing (Anonymous, 1975).Fruit firmness is one of the most important quality attribute; this helps to measure fruit ripeness and also it sets standards for export of particular product (Garcia et al., 2005). This parameter is used in combination with others attributes like sugar and acid content, represent important parameters used in the objective evaluation of fruit and vegetable quality. Among, these three, firmness probably remains the most subjective, because the relatively simple output of the force of a probe on fruit surfaces is used to interpret complex rheological behavior (Muramatsu et al., 1997). In certain cases like kiwifruit, Sapota, granny smith apple there is no external color change this causes problem in judging its maturity (Muramatsu et al., 1997). Hence, an additional comprehensive non-destructive method for product evaluation would have distinct advantages for quality control. Several methods for nondestructive firmness measurement have been reported by several researchers for different food products. (Falket al., 1958; Finney 1970; Yamamoto and Haginuma, 1984 and Abbott, 1994).Due to the technological advances over the past few decades have led to the evolution of several non-destructive techniques like image processing, visible and infrared light inspection, acoustic vibration technique, NMR technique and mechanical simulation capable of measuring product internal variables. Initially, these were developed to utilize in the laboratory, but have been fitted for on-line use. This article describes detailed methodology, components, working principle and applications of acoustic vibration technique to measure or assess the quality of the food products.

\section{Non-destructive quality evaluation}

Several methods are emerged out to evaluate the texture of agricultural products based on deformation force (e.g., the puncture test and compression test). The quality evaluation of agricultural products is supposed to be an inspection of samples when we use these methods because they are destructive. For better quality control of agricultural products, one hundred percent inspection is preferable; therefore, nondestructive evaluation methods are highly in demand. Therefore, there is immediate need of novel techniques to combat against these problems.

\section{Deformation method}

Deformation methods are considered to be non-destructive as long as the deformation is small enough not to damage an agricultural product. The Hertz's theory is the basic principle governing the measurement of deformation force; the compressive stress between two bodies in contact is proportional to their elastic modulus and inversely proportional to their radius. Here, one of the bodies is the fruit and the other a metallic plunger (either a small sphere or flat-ended probe). By applying a small deformation force to the fruit in such that it causes no damage, the non-destructive force-deformation curve can be recorded using an analogue or a piezoelectric sensor positioned at the back of the compression plunger. The curve is produced by applying a small load for a fixed period of time (Macnish et al., 1997) or by calculating the force necessary to reach a preset deformation (Fekete and Felfoldi, 2000).

\section{Acoustic vibration technique}

When an acoustic wave reaches a food product, the reflected or transmitted acoustic wave depends on the characteristics of the product. Acoustic technology is often used to 
estimate product firmness along with other quality parameters (Maristella and Marina, 2012). Acoustic firmness index is based on the relationship between modulus of elasticity and the resonant frequencies of vibration of the fruit. The acoustic vibration technique further classified according to sensors for vibration detection and excitation methods (Figure 1). There are two kinds of sensors: contact and noncontact sensors. Contact sensors are directly attached to the surface of the sample under examination. Such sensors that are commonly used include acceleration pickups and piezoelectric sensors. Noncontact sensors include microphones and optical sensors such as laser Doppler vibrometers (LDVs) and laser interferometers. The advantages of noncontact sensors are that they are totally non-destructive and exert no physical or mechanical influence; therefore, they do not damage the surface of a sample. The acoustic response technique for measuring fruit firmness has been studied with two different approaches: involving values within the audible spectrum (sonic) or using ultrasound (Maristella and Marina, 2012). According to Subedi and Walsh (2009), the sound velocity of the vibration produced by the fruit hit by a plastic plunger, detected by two unidirectional microphones, was demonstrated to non-destructively assess the ripening stage of banana, mango and peach fruits, although it does not measure the same property as the penetrometer whereas the vibrational response of pear (Terasaki et al., 2006; Taniwaki et al., 2009), melon (Taniwaki et al., 2009; Taniwaki et al., 2010) and persimmon fruits was sensed by means of a laser Doppler vibrometer and an acceleration pickup and the Elasticity Index, determined by using both signals, highly correlated with the results of a sensory test. The several studies reveal that the Acoustic Vibration Technique can be useful for predicting the optimum ripeness for edibility of these fruits but that the difference in texture attributes is explainable only in part by the frequency bands.

The several vibration techniques are used in analyzing the food quality, among them acoustic and mechanical are very common. Using a microphone or a piezoelectric sensor, acoustic methods measure the signal (audible range: about $0-20,000 \mathrm{~Hz}$ ) issued by the fruit after making it vibrate by means of a small impact. The acoustic signal captured is Fourier Transformed and the main frequency calculated. The range varies from $5 \mathrm{Mpa}$ for green fruit to $0.5 \mathrm{MPa}$ for overripe fruit (Studman, 1999).

\section{Components of the acoustic vibration equipment}

Basically the experimental setup consists of a platform over which the sample was placed. Sensitive sensors (contact type or non-contact type) like Microphone, piezoelectric sensors, Laser Doppler Vibrometer or any other sensors were placed either attached to the product or in other indirect form to sense the vibration or frequency after applying the little force to the product. Force required to generate the vibration can be applied with the help of pendulum arrangement consisting of either ball or small probe. Then the quality parameters of the product can be determined by analyzing the frequency or vibration with the help of Fast Fourier Transformation (FFT) analyzer. Typical experimental setup of Acoustic vibration equipment and all its components are shown in figure 2.

Then the frequency ' $f$ ' of the model is given by;

$$
f=\frac{1}{2 \pi} \sqrt{\frac{4 k}{m}} \quad \text { and } \quad k=\pi^{2} f^{2} m
$$


Where ' $\mathrm{k}$ ' is the spring constant of the system and ' $\mathrm{m}$ ' is the mass of the sample. In order to assess the quality and maturity indices of fruits and vegetables, various parameters were considered which are tabulated in table 1.

Table.1 Various parameters applied to assess the quality and maturity indices of fruits and vegetables

\begin{tabular}{|c|c|c|c|}
\hline Sl. No & Index & $\begin{array}{l}\text { Method of } \\
\text { Determination }\end{array}$ & Examples \\
\hline 1. & $\begin{array}{l}\text { Elapsed days from full bloom to } \\
\text { harvest }\end{array}$ & Computation & Apples, pears \\
\hline 2. & $\begin{array}{l}\text { Mean heat units during } \\
\text { development }\end{array}$ & $\begin{array}{l}\text { Computation from } \\
\text { weather data }\end{array}$ & Apple \\
\hline 3. & Development of abscission layer & $\begin{array}{l}\text { Visual or force of } \\
\text { separation }\end{array}$ & $\begin{array}{l}\text { Some melons, apples, } \\
\text { feijoas }\end{array}$ \\
\hline 4. & Surface morphology and structure & Visual & $\begin{array}{l}\text { Cuticle formation on } \\
\text { grapes, tomatoes; } \\
\text { netting of some melons; } \\
\text { gloss of some fruits } \\
\text { (development of wax) }\end{array}$ \\
\hline 5. & Size & $\begin{array}{l}\text { Various measuring } \\
\text { device, weight }\end{array}$ & All fruits \\
\hline 6. & Specific gravity & $\begin{array}{l}\text { Density gradient solution; } \\
\text { flotation techniques; } \\
\text { volume/weight }\end{array}$ & Cherries, watermelons \\
\hline 7. & Shape & Dimensions; ratio charts & $\begin{array}{l}\text { Angularity of banana } \\
\text { finger; full cheeks of } \\
\text { Mangoes }\end{array}$ \\
\hline 8. & Firmness & $\begin{array}{l}\text { Firmness tester, } \\
\text { deformation }\end{array}$ & Apples, pears, stone fruits \\
\hline 9. & External colour & $\begin{array}{l}\text { Light reflectance, visual } \\
\text { colour charts }\end{array}$ & All fruits \\
\hline 10. & Internal colour and structure & $\begin{array}{l}\text { Light transmittance, } \\
\text { delayed light emission, } \\
\text { visual examination }\end{array}$ & Flesh colour of some fruits \\
\hline 11. & Total solids & Dry weight & Avocados, kiwifruit \\
\hline 12. & Starch content & $\begin{array}{l}\text { KI test, other chemical } \\
\text { tests }\end{array}$ & Apples, pears \\
\hline 13. & Sugar content & $\begin{array}{l}\text { Hand refractometer, } \\
\text { chemical tests }\end{array}$ & $\begin{array}{l}\text { Apples, pears, stone fruits, } \\
\text { grapes }\end{array}$ \\
\hline 14. & Acid content, sugar/acid ratio & Titration, chemical tests & $\begin{array}{l}\text { Pomegranates, citrus, } \\
\text { papaya, kiwifruit }\end{array}$ \\
\hline 15. & Juice content & Extraction & Citrus fruits \\
\hline 16. & Oil content & Extraction, chemical tests & Avocados \\
\hline 17. & Astringency (tannin content) & Ferric chloride test & Persimmons, dates \\
\hline 18. & Internal ethylene concentration & Gas chromatography & Apples, pears \\
\hline
\end{tabular}


Table.2 Methods and parameters used for non-destructive evaluation of different products

\begin{tabular}{|c|c|c|c|}
\hline Crop & Method & Parameters used & Reference \\
\hline Apple & $\begin{array}{ll}\text { Acoustic, } & \text { VIS-NIR } \\
\text { spectroscopy } & \end{array}$ & $\begin{array}{l}\text { Acoustic resonance frequency, fruit } \\
\text { absorbance }\end{array}$ & Zude et al., 2006 \\
\hline Apple & Acoustic (ultrasound) & Wave velocity & Kim et al., 2009 \\
\hline Apple & $\begin{array}{l}\text { Acoustic, low mass } \\
\text { impact, impact test, } \\
\text { compression } \\
\text { puncture test }\end{array}$ & $\begin{array}{l}\text { Maximum deformation, maximum } \\
\text { force, acoustic frequency }\end{array}$ & $\begin{array}{l}\text { Molina-Delgado et } \\
\text { al., } 2009\end{array}$ \\
\hline $\begin{array}{l}\text { Banana, } \\
\text { mango, } \\
\text { peach }\end{array}$ & Acoustic & Sound velocity & Subedi et al., 2009 \\
\hline Kiwifruit & Dynamic impact & Peak of force, pulse duration, impulse & Ragni et al., 2010 \\
\hline $\begin{array}{l}\text { Melon, } \\
\text { persimmon, } \\
\text { pear }\end{array}$ & Acoustic & Resonant frequency & $\begin{array}{l}\text { Terasaki et al., } \\
\text { 2006Taniwaki et al. } \\
\text { 2009a }\end{array}$ \\
\hline Orange & Acoustic (ultrasound) & Wave velocity and amplitude & $\begin{array}{l}\text { Camarena } \text { et al., } \\
2006, \text { Jiménez } \text { et al., } \\
2012\end{array}$ \\
\hline Peach & Impact and acoustic & $\begin{array}{l}\text { Maximum acceleration, resonant } \\
\text { frequency Spectrum amplitude, band } \\
\text { magnitude }\end{array}$ & $\begin{array}{l}\text { Diezma-Iglesias } \\
\text { et al., } 2006\end{array}$ \\
\hline Peach & Impact & Resonance frequency & Wang et al., 2006 \\
\hline $\begin{array}{l}\text { Peach, } \\
\text { nectarin, } \\
\text { plum }\end{array}$ & Hammer impact & SFI score from SIQ firmness tester & Valero et al.,2007 \\
\hline Peach & $\begin{array}{l}\text { VIS spectroscopy, } \\
\text { impact, deformation test }\end{array}$ & $\begin{array}{l}\text { Force and time impact, maximum force, } \\
\text { reflectance R680 and R } 450\end{array}$ & $\begin{array}{l}\text { Ruiz-Altisent et al., } \\
2006\end{array}$ \\
\hline Peach & Impact and acoustic & $\begin{array}{l}\text { Resonance frequency of the first } \\
\text { elliptical mode }\end{array}$ & $\begin{array}{l}\text { Ruiz-Altisent et al., } \\
2010\end{array}$ \\
\hline Peach & $\begin{array}{l}\text { VIS spectroscopy, } \\
\text { impact }\end{array}$ & $\begin{array}{l}\text { Reflectance, maximum impact } \\
\text { acceleration, impact hardness, time for } \\
\text { maximum acceleration, maximum } \\
\text { deformation }\end{array}$ & $\begin{array}{l}\text { Herrero-Langreo et } \\
\text { al., } 2012\end{array}$ \\
\hline Pear & Ball impact & Resonant frequency & $\begin{array}{l}\text { Hernandez-Gomez et } \\
\text { al., } 2005\end{array}$ \\
\hline Tomato & Acoustic (ultrasound) & Wave attenuation & Mizrach, 2007 \\
\hline $\begin{array}{l}\text { Tomato, } \\
\text { apple }\end{array}$ & Impact and acoustic & $\begin{array}{l}\text { "SIQ-FT" index (calculated by force } \\
\text { peak } \\
\text { amplitude and impact response). } \\
\text { Resonant frequency }\end{array}$ & $\begin{array}{l}\text { De Ketelaere et } \\
\text { al., } 2006\end{array}$ \\
\hline
\end{tabular}


Figure.1 Classification of acoustic vibration technique

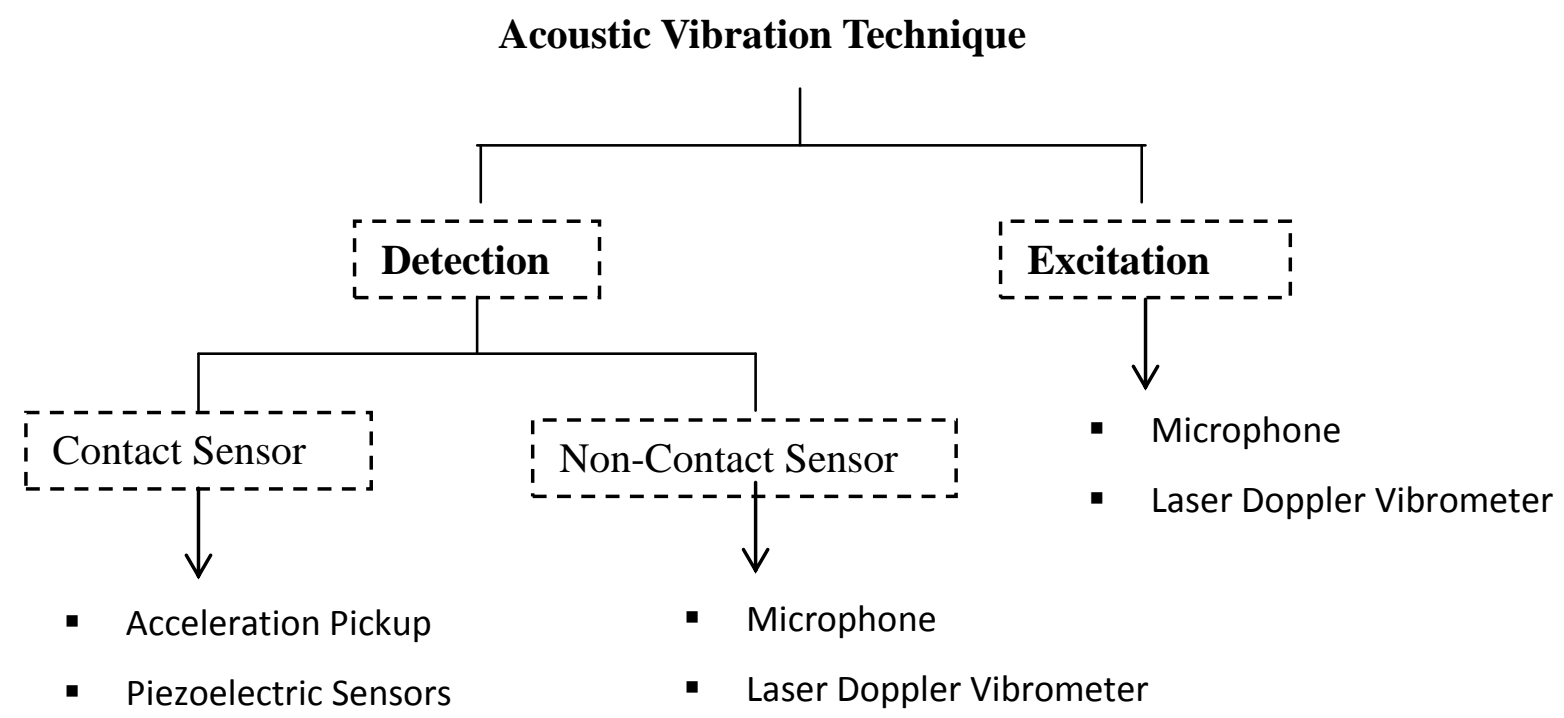

Figure.2 Experimental setup for excitation by impact and detection by piezoelectric sensor based acoustic vibration technique. Applications of the acoustic vibration technique in quality

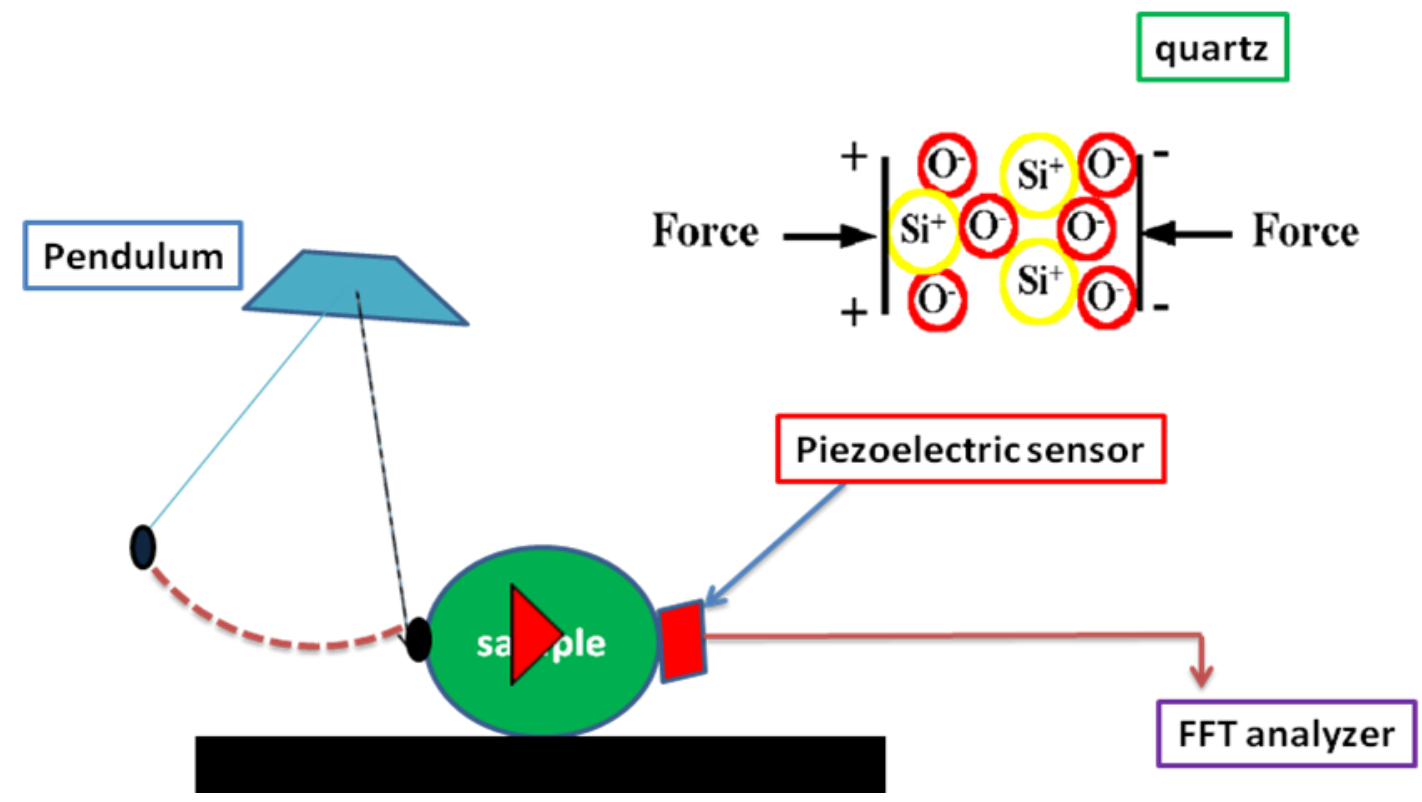

In destructive methods of analysis of quality is done based on the selection of random representative sample. The tendency of using as few samples as possible often results in increased lot to lot variability in the parameter measured. At harvest there is always variability among picked fruits even when, on the average, they conform to the harvest parameters. In contrast, non-destructive methods can be applied to a large number or even to all fruits and non-destructive analyses can be repeated on the same samples, monitoring their physiological changes (Nicolai et al., 2007). A number of reviews on 
non-invasive technologies for fruit and quality sensing have been published concerning visible (VIS) and near infrared (NIR) spectroscopy, multi- and hyperspectral imaging, time- and space-resolved reflectance spectroscopy, computer vision, nuclear magnetic resonance (NMR) and magnetic resonant imaging (MRI), acoustic methods and wireless sensing (Ruiz-Altisent et al., 2010). This review highlights spectral maturity indices as well as nondestructive mechanical techniques developed in the last few years for the assessment of fruit ripening (Table 2). This table indicates various methods employed and parameters investigated for non-destructive evaluation of different horticulture crops.

In conclusion the development of costeffective and practical well adapted nondestructive techniques for evaluating the perishable agriculture goods. Another approach is to gain a theoretically in-depth understanding of the acoustic vibrations of agricultural products. Although there have been studies on the vibrational modes of different shapes (Cherng, 2000; Cherng and Ouyang, 2003; Jancsok et al., 2001) for instance, the vibrational characteristics of agricultural products, such as watermelons, that consist of two-layered spherical shells have not been fully analyzed. Understanding such dynamics would help in developing a methodology for obtaining inner quality information on agricultural products. The AVT used for quality estimation are simple, cheap and acceptable results were obtained, but non-destructive techniques do not necessarily measure the same quality attribute as their destructive counterparts. Moreover, the authors often observed poor relationships between acoustic firmness and M-T test, and non-destructive impact measurements were found to be highly sensitive to change in turgidity but less able to follow changes in ripening. Future studies should focus on the simultaneous use of different ND techniques. In such a way the resulting information is more complete and accurate than that obtained when an individual technique has been used.

\section{References}

Abbott, J.A., 1994. Firmness measurement of freshly harvested 'Delicious apple' by sensory method, sonic transmission, Magness-Taylor and compression. $J$. Am. Soc. Hortic. Sci.119: 510-515.

Anonymous, 1975.Glossary of terms relating to the sensory analysis of food. British Standard 5098.British Standards Institution, London.

Camarena F. and Martinez-Mora J.A., 2006.Potential of ultrasound to evaluate turgidity and hydration of the orange peel.Journal of Food Engineering.75: 503-507.

Cherng, A. P. and Ouyang F., 2003.A firmness index for fruits of ellipsoidal shape.Biosys. Eng.86: 35-44.

Cherng, A. P., 2000. Vibration modes of melons of ellipsoidal shape. Trans. ASAE.43: 1185-1193.

De Ketelaere B., Scott Howarth M., Crezee L., Lammertynd J., Viaene K., Bulens I. and De Baerdemaeker J., 2006. Postharvest firmness changes as measured by acoustic and low-mass impact devices: a comparison of techniques. Postharvest Biology and Technology.41: 275-284.

Diezma-Iglesias B., Valero C., Garcìa-Ramos F. J. and Ruiz-Altisent M., 2006. Monitoring of firmness evolution of peaches during storage by combining acoustic and impact methods. Journal of Food Engineering.77: 926-935.

Falk S., Hertz, C.H., and Virgin, H.I., 1958. On the relation between turgor pressure and its relation to fruits rigidity. Physiol. Plant. 11: 802-807. 
Fekete A. and Felföldi J., 2000. System for fruit firmness evaluation. Proc Int. Conf. Agricultural Engineering. Warwick, UK, July 2-7. Paper 00-PH034.

Finney E.E., 1970. Mechanical resonance within 'Red Delicious' apples and its relation to fruits texture. Trans. ASAE. 13: $177-180$.

Garcia-Ramos F. J., Valero C., Homer I., Ortiz-CañavateJ. and Ruiz-Altisent M., 2005. Non-destructive fruit firmness sensors: a review. Spanish Journal of Agricultural Research. 3(1): 61-73.

Hernandez-Gomez A., Wang J. and Garcìa Pereira A., 2005.Impulse response of pear fruit and its relation to MagnessTaylor firmness during storage. Postharvest Biology and Technology.35: 209-2015.

Herrero-Langreo A., Fernández-Ahumada E., Roger J.M., Palagós B. and Lleó L., 2012.Combination of optical and nondestructive techniques for the measurement of maturity in peach. Journal of Food Engineering.108: 150 157.

Jancsok, P. T., Clijmans L., Nicolai B. M. and De Baerdemaeker J., 2001.Investigation of the effect of shape on the acoustic response of 'conference' pears by finite element modelling. Postharvest Biol. Technol.23: 1-12.

Kim K.B, Lee S., Kim M.S., and Cho B.K., 2009.Determination of apple firmness by nondestructive ultrasonic measurement. Postharvest Biology and Technology.52: 44-48.

Macnish A.J., Joyce D.C., Shorter A.J., 1997. A simple non-destructive method for laboratory evaluation of fruit firmness. Aust. J. Exp. Agr. 37: 709-13.

MaristellaVanolia and Marina Buccheria, 2012. Overview of the methods for assessing harvest maturity. Stewart Postharvest Review. 1 - 4.
Mitsuru Taniwaki and Naoki Sakurai, 2010.Evaluation of the internal quality of agricultural products using acoustic vibration techniques. J. Japan. Soc. Hort. Sci.79(2): 113-128.

Mizrach A., 2007. Nondestructive ultrasonic monitoring of tomato quality during shelf-life storage. Postharvest Biology and Technology.46: 271-274.

Molina-Delgado D., Alegrec S., Barreirod P., Valerod C., Ruiz-Altisent M. and Recasens I., 2009. Addressing potential sources of variation in several nondestructive techniques for measuring firmness in apples. Biosystems Engineering. 104: 33-46.

Nicolai B.M., Beullens K., Bobelyn E., Peirs A., Saeys W., Theron K.I. and Lammertyn J., 2007. Nondestructive measurement of fruit and vegetable quality by means of NIR spectroscopy: A review. Postharvest Biology and Technology.46: 99-118.

Ragni L., Berardinelli A. and Guarnieri A., 2010.Impact device for measuring the flesh firmness of kiwi. Journal of Food Engineering.591-597.

Ruiz-Altisent M., Lleó L. and Riquelme F., 2006. Instrumental quality assessment of peaches: fusion of optical and mechanical parameters. Journal of Food Engineering.74: 490-499.

Ruiz-Altisent M., Ruiz-Garcia L., Moreda G.P., Lu R., Hernandez-Sanchez N., Correa E.C., Diezma B., Nicolaï B. and García-Ramos J., 2010. Sensors for product characterization and quality of specialty crops.A review. Computers and Electronics in Agriculture.74:76194.

Studman C.J, 1999. Fruit and vegetables: fruit and vegetable quality. CIGR ed. CIGR Handbook of Agriculture Engineering, Vol. IV. pp. 243-72.

Subedi P. and Walsh K.B., 2009.Noninvasive techniques for measurement of 
fresh fruit firmness. Postharvest Biology and Technology.51: 297-304.

Taniwaki M., Hanada T., Tohro M. and Sakurai N., 2009a.Non-destructive determination of the optimum eating ripeness of pears and their texture measurements using acoustical vibration techniques. Postharvest Biology and Technology.51: 305-310.

Taniwaki M., Takahashi M. and Sakurai N., 2009b.Determination of optimum ripeness for edibility of postharvest melons using nondestructive vibration. Food Research International.42: 137 141.

Taniwaki M., Tohro M. and Sakurai N., 2010c.Measurement of ripening speed and determination of the optimum ripeness of melons by a nondestructive acoustic vibration method. Postharvest Biology and Technology.56: 101-103.

Terasaki S., Sakurai N., Zebrowski J., Murayama H., Yamamoto R. and Nevins D.J., 2006. Laser Doppler vibrometer analysis of changes in elastic properties of ripening ' $\mathrm{La}$ France' pears after postharvest storage. Postharvest Biology and Technology.42: 198-207.

Valero C., Crisosto C.H. and Slaughter D., 2007. Relationship between nondestructive firmness measurements and commercially important ripening fruit stages for peaches, nectarines and plums. Postharvest Biology and Technology.44: 248-253.

Wang J., Teng B. and Yu Y., 2006.The firmness detection by excitation dynamic characteristics for peach. Food Control.17: 353-358.

Yamamoto H. and Haginuma S., 1984a.Estimation of the dynamic Young's modules of apple flesh from the natural frequency of an intact apple. Rep. Natl. Food Res. Inst.44: 20-25.

Yamamoto H. and Haginuma, S., 1984b.Dynamic viscoelastic properties and acoustic properties of Watermelons. Rep.Natl. Food Res. Inst. 44: 30-35.

Yamamoto, H., Haginuma, S., 1984c.Dynamic viscoelastic properties and acoustic properties of Japanese radish (Shogoin) roots. Rep. Natl. Food. Res. Inst. 44: 36-44.

Zude M., Herold B., Roger J.M., BellonMaurel V. and Landahal S., 2006. Nondestructive tests on the prediction of apple fruit flesh firmness and soluble solids content on tree and in shelf life. Journal of Food Engineering.77: 254260.

\section{How to cite this article:}

Shrikrishna Nishani, Shrinivas Deshpande and Gajanan Gundewadi. 2017. Use of Acoustics as Non-Destructive Techniques: A Review. Int.J.Curr.Microbiol.App.Sci. 6(6): 2468-2476. doi: https://doi.org/10.20546/ijcmas.2017.606.293 